\title{
Biochemical and Physiological Changes during Thermal Stress in Bovines
}

\author{
A.H. Ganaie ${ }^{1}$, Gauri Shanker ${ }^{1}$, Nazir A. Bumla ${ }^{1}$, Ghasura R.S ${ }^{2}$, N.A. Mir ${ }^{3}$, Wani SA ${ }^{3}$ and Dudhatra GB ${ }^{4 *}$ \\ ${ }^{1}$ Department of Animal Physiology and Biochemistry, ACVM, Agra Road, Jaipur, India \\ ${ }^{2}$ Department of Veterinary and Animal Husbandry Extension, College of Veterinary Science and Animal Husbandry, SDAU, Gujarat, India \\ ${ }^{3}$ Department of Animal Physiology, National Dairy Research Institute, Karnal, India \\ ${ }^{4}$ Department of Pharmacology and Toxicology, College of Veterinary Science and Animal Husbandry, SDAU, Gujarat, India
}

\begin{abstract}
Thermal stress is a major cause of production losses in the dairy and beef industries. Dairy animals are more heat sensitive as average milk yield has increased. During thermal stress physiological and biochemical changes occurs in the animal body which directly or indirectly affect the production. This review clearly describes about biochemical and physiological changes occur during thermal stress in bovines.
\end{abstract}

Keywords: Thermal stress; Bovines; Physiological changes; Biochemical changes

\section{Introduction}

Climate change, defined as the long-term imbalance of customary weather conditions such as temperature, radiation, wind and rainfall characteristics of a particular region, is likely to be one of the main challenges for mankind during the present century. The earth's climate has warmed in the last century $\left(0.74 \pm 0.18^{\circ} \mathrm{C}\right)$ with the $1990 \mathrm{~s}$ and $2000 \mathrm{~s}$ being the warmest on instrumental record (Intergovernmental Panel on Climate Change (IPCC), 2007). Furthermore, the earth's climate has been predicted to change continuously at rates unprecedented in recent human history (IPCC, 2007). Current climate models indicated an increase in temperature by $0.2^{\circ} \mathrm{C}$ per decade and predicted that the increase in global average surface temperature would be between $1.8^{\circ} \mathrm{C}$ to $4.0^{\circ} \mathrm{C}$ by 2100 (IPCC, 2007).

The variation in climatic variables like temperature, humidity and radiations were recognized as the potential hazards in the growth and production of all domestic livestock species. High ambient temperature accompanied by high air humidity caused an additional discomfort and enhanced the stress level which in turn resulted in depression of the physiological and metabolic activities of this animal.

Stress has been defined by several workers. As per Dobson and Smith [1], it is revealed by the inability of an animal to cope up with its environment, a phenomenon which is often reflected in a failure to achieve genetic potential. Rosales [2] defined stress as the cumulative detrimental effect of various factors on health and performance of animals. Stress represents the reaction of body to stimuli that disturb normal physiological equilibrium or homeostasis, often with detrimental effects as shown by Khansari et al. [3]. According to Stott [4], stress is the result of environmental forces continuously acting upon animals which disrupt homeostasis resulting in new adaptations that can be detrimental or advantageous to the animal.

Among the stressors, heat stress has been of major concern in reducing animal's productivity in tropical, sub-tropical and arid areas [5]. The degree to which an animal resists change in body temperature varies with different species because of differences in their heat regulating mechanisms [6]. Under thermal stress, a number of physiological and behavioral responses vary in intensity and duration in relation to the animal genetic make-up and environmental factors through the integration of many organs and systems viz. behavioral, endocrine, cardio-respiratory and immune system [7]. Sweating, high respiration rate, vasodilation with increased blood flow to skin surface, high rectal temperature, reduced metabolic rate, decreased DM intake, efficiency of feed utilization and altered water metabolism are the physiologic responses that are associated with negative impacts of heat stress on production and reproduction in dairy animals [8].

Buffaloes have poor heat tolerance capacity compared to other domestic ruminants [9], and are more prone to heat stress due to scarcely distributed sweat glands, dark body colour and sparse hair on body surface [10]. The water buffalo has only $1 / 10^{\text {th }}$ the number of sweat glands per unit area of skin compared to zebu cattle and must rely on wallowing or wetting of the skin during heat conditions to reduce heat load. Air temperature $\left(13-18^{\circ} \mathrm{C}\right), \mathrm{RH}(55-65 \%)$ and wind velocity (5-8 $\mathrm{km} / \mathrm{h}$ ) are the optimum conditions for buffaloes as suggested by Payne (1990). In terms of THI, the values of THI $>72$ is considered as stressful and THI $>78$ is considered very severe heat stress to this animal.

Reactions of homeotherms to moderate climatic changes are compensatory and are directed at restoring thermal balance [8]. However, when environmental temperature becomes near the animal's body temperature, high ambient relative humidity reduces evaporation, overwhelms the animal's cooling capacity and the body temperature rises. The increasing concern of thermal discomfort of farm animals is debatable not only for countries of tropical zones, but also for nations of temperate zones in which ambient temperatures is increasing due to climate change [11]. In terms of adaptation measures, it is generally faster to improve welfare, production and reproduction performances of animals by altering their micro-environment [12,13]. Despite its importance, there are few effective strategies for reducing the effects of heat stress on animal's health and performance. The major strategies providing elaborate housing involving shade, sprinklers, fans, air conditioner etc. are capital intensive, not very efficient and is of limited use for small and medium size dairies. There is thus need for research in developing alternative approaches to reduce thermal stress.

*Corresponding author: Dudhatra GB, Department of Pharmacology and Toxicology, College of Veterinary Science and Animal Husbandry, SDAU, India, E-mail: drgvets@gmail.com

Received November 20, 2012; Accepted December 26, 2012; Published December 28, 2012

Citation: Ganaie AH, Shanker G, Bumla NA, Ghasura RS, Mir NA (2013) Biochemical and Physiological Changes during Thermal Stress in Bovines. Veterinar Sci Technol 4: 126. doi:10.4172/2157-7579.1000126

Copyright: (c) 2013 Ganaie $\mathrm{AH}$, et al. This is an open-access article distributed under the terms of the Creative Commons Attribution License, which permits unrestricted use, distribution, and reproduction in any medium, provided the original author and source are credited. 


\section{Oxidative stress}

Oxidative stress results from increased production of free radicals and reactive oxygen species, and a decrease in antioxidant defense $[14,15]$ reported that oxidation is essential to nearly all cells in the body to provide energy for vital functions. Approximately 95 to $98 \%$ of the oxygen consumed is reduced to water during aerobic metabolism, but the remaining fraction may be converted to oxidative by-products-reactive oxygen species, that may damage the DNA of genes and contribute to degenerative changes. One of the main reasons for oxidative stress in animals during summer in tropics is heat stress. Heat stress occurs when the core body temperature of a given species exceeds its range specified for normal activity resulting from a total heat load (internal heat production and heat gained from environment) exceeding the capacity for heat dissipation.

\section{Antioxidants}

Antioxidants are those nutrients which are required to cleanse cells of ROS. Vitamin E, vitamin A and vitamin C are classic examples of antioxidants. Antioxidant in low concentrations significantly delays or inhibits oxidation of oxidizable substrates.

Antioxidants can be divided into 3 major groups: Enzymatic (SOD, CAT, GPX), Non-enzymatic (Albumin, L-cysteine, homocysteine and Protein sulfhydryl groups) and Non-enzymatic low molecular weight antioxidants (ascorbic acid, glutathione, uric acid $\alpha$-tocopherol, $\beta$-carotene and retinol).

Tissue defense mechanisms against free-radical damage generally include vitamin $\mathrm{C}$, vitamin $\mathrm{E}$, and $\beta$ carotene as the major vitamin antioxidant sources. In addition, several metalloenzymes which include glutathione peroxidase (Se), catalase $(\mathrm{Fe})$ and superoxide dismutase $(\mathrm{Cu}, \mathrm{Zn}$, and $\mathrm{Mn})$ are also critical in protecting the internal cellular constituents from oxidative damage (Weiss, 2006).

\section{Superoxide Dismutase (SOD)}

Superoxide dismutase (SOD) was first isolated by Mann and Keilin [16] and thought to be a copper storage protein. Subsequently, the enzyme was named as erythrocuprein, indophenol oxidase, and tetrazolium oxidase until its catalytic function was discovered by McCord and Fridovich [17]. SOD is now known to catalyse the dismutation of superoxide to hydrogen peroxide and oxygen.

$$
{ }^{\circ} \mathrm{O}_{2}^{-}+{ }^{\circ} \mathrm{O}_{2}^{-}+2 \mathrm{H}^{+} \longrightarrow \mathrm{H}_{2} \mathrm{O}_{2}+\mathrm{O}_{2}
$$

The major defense in detoxification of superoxide anion and hydrogen peroxide, are superoxide dismutase (SOD), catalase and glutathione peroxidase $[17,18]$.

Pathan et al. [19] observed increase in the concentration of SOD with the advancement of pregnancy. The SOD concentration was significantly higher on the day of parturition $(3.03 \pm 0.13 \mathrm{U} / \mathrm{ml})$ compared to day 30 before parturition $(2.13 \pm 0.19 \mathrm{U} / \mathrm{ml})$. Bernabucci et al. [20] also observed increase in SOD and GPX concentration in prepartum cows with peaks around calving during summer month. The SOD and GPX levels were $176.4 \pm 19.8$ and $65.7 \pm 3.9$ units/g $\mathrm{Hb}$ respectively at day 21 and $215.3 \pm 21.3$ and $69.4 \pm 4.2$ units/g Hb respectively at day 1 after parturition. Megahed et al. [21] examined the effects of heat stress in Egyptian buffaloes in summer and winter seasons and reported that superoxide (SOD) activities were significantly lower in the summer $(3.17 \pm 0.13 \mathrm{U} / \mathrm{ml})$ compared to winter $(3.8 \pm$ $0.16 \mathrm{U} / \mathrm{ml}$ ) season. Chandra and Aggarwal [22] also reported higher SOD levels in prepartum crossbred cows during summer $(3.83 \pm 13.59$
$\mathrm{mM} / \mathrm{l})$ compared to winter $(3.39 \pm 16.50 \mathrm{mM} / \mathrm{l})$ season indicating effect of hot summer season on the oxidative status of transition dairy cows. Lallawmkimi [23] studied the effect of winter and summer seasons on antioxidant status of growing, heifer and lactating Murrah buffaloes and reported significantly higher SOD levels during summer compared to winter in all the three experimental groups.

\section{Catalase (CAT)}

Catalase is a heme-containing enzyme that catalyses the dismutation of hydrogen peroxide into water and oxygen. In peroxisomes catalase takes care of the cytosolic and mitochondrial peroxides formed during urate oxidation [24]. Mitochondrial SOD readily converts the bulk of mitochondrial superoxide ions to $\mathrm{H}_{2} \mathrm{O}_{2}$. Thus, SOD and catalase protects the cell from the damage due to the secondary generation of highly reactive hydroxyl group from superoxide ion to $\mathrm{H}_{2} \mathrm{O}_{2}$ [25].

Kumar [26] observed a significant positive correlation of THI with the erythrocyte catalase activity in Murrah buffalo and KF cattle. The highest increase in catalase activity was registered in KF followed by Murrah buffaloes. Lallawmkimi [27] studied the effect of winter and summer seasons on antioxidant status of growing, heifer and lactating Murrah buffaloes and reported significantly higher catalase actvity during summer compared to winter in all the three experimental groups. Further, Chandra and Aggarwal [22] also reported higher catalase activity in prepartum crossbred cows during summer (159.94 $\pm 0.10 \mu \mathrm{mol} / \mathrm{min} / \mathrm{mgHb}$ ) compared to winter $(153.85 \pm 0.08 \mu \mathrm{mol} / \mathrm{min} /$ $\mathrm{mgHb}$ ) season.

\section{Glutathione peroxidase (GPX)}

GPX is a selenium dependent antioxidant enzyme. It converts $\mathrm{H}_{2} \mathrm{O}_{2}$ to water. The increased production of $\mathrm{H}_{2} \mathrm{O}_{2}$ due to increased activity of SOD during heat stress resulted in a coordinated increase in GPX.

Bisla et al. [28] reported that GSH concentration increased due to oxidative stress caused by diaphragmatic herniorrhaphy in buffaloes. The concentration of erythrocytic GSH-PX increased with the advancement of pregnancy in buffaloes and its concentration was significantly higher on the day of parturition $(912.59 \pm 17.46 \mathrm{U} / \mathrm{ml})$ compared to day 30 before parturition $(819.41 \pm 22.33 \mathrm{U} / \mathrm{ml})$ [19]. Bernabucci et al. [29] also reported an increase in serum SOD and GPX concentrations during summer in prepartum cows with peaks reaching around calving. The serum SOD and GPX levels were 176.4 \pm 19.8 and $65.7 \pm 3.9$ units respectively at day 21 and $215.3 \pm 21.3$ and $69.4 \pm 4.2$ units respectively at day 1 after parturition.

Lallawmkimi [23] studied the effect of winter and summer seasons on antioxidant status of growing calves, heifers and lactating Murrah buffaloes and reported significantly higher GPx concentrations during summer compared to winter in all the three experimental groups.

\section{Thiobarbituric Acid Reactive Substance (TBARS)}

Lipid peroxidation is commonly measured in terms of TBARS Erythrocyte being rich in Polyunsaturated Fatty Acids (PUFA) being exposed to high concentration of oxygen and are highly susceptible to peroxidation damage [30]. Oxidative stress can lead to increase in TBARS [31]. Unsaturated fatty acid oxidation by ROS in the presence of iron generates additional lipid centric radicals [31] through the Fenton's reaction that leads to the formation of lipid hydro-peroxides [14]. ROS status in animals is often determined using the TBARS assay that measures acetaldehyde generated from products of lipid peroxidation. TBARS can induce a reduction of membrane fluidity and increase erythrocyte membrane fragility [32]. 
The erythrocyte TBARS concentration increased in heat exposed cattle and buffalo [33]. Similar increase in TBARS concentration was observed in heat exposed Holstein cows by Bernabucci et al. [29]. Dietary supplementation of ascorbic acid resulted in lower TBARS concentration [34]. This is due to the fact that ascorbic acid acts as a chain blocker of lipid peroxidation. The role of ascorbic acid in controlling lipid peroxidation in erythrocyte has been demonstrated in vitro [35]. The increase of thiobarbituric acid reactive substance (TBARS) immediately before and after calving confirmed that cows during the transition period were under oxidative stress [36]. TBARS concentration was also higher during summer $(6.23 \pm 0.02 \mathrm{nmol} / \mathrm{ml})$ in prepartum crossbred cows compared to winter season $(5.37 \pm 0.07$ $\mathrm{nmol} / \mathrm{ml}$ ) as reported by Chandra and Aggarwal [22]. The TBARS concentration increased from $8.3 \pm 0.4 \mathrm{nmol} / \mathrm{ml}$ at day 21 to $10.2 \pm$ $0.4 \mathrm{~nm} / \mathrm{ml}$ at day 1 after calving. Aengwanich et al. [37] studied the effect of hot summer on cattle maintained under artificial shade, tree shade and no shade conditions. The authors observed that there was a significant higher concentration of TBARS in no shade (33.29 \pm 9.40 $\mu \mathrm{mol} / \mathrm{l})$ compared to artificial $(25.64 \pm 8.35 \mu \mathrm{mol} / \mathrm{l})$ and tree shade $(25.25 \pm 2.05 \mu \mathrm{mol} / \mathrm{l})$ animals.

\section{Plasma protein}

More et al. [38] reported a significant increase in the serum protein of sheep exposed to heat stress. The increase in serum protein could be a physiological attempt to maintain extended plasma volume. Raghavan and Mullick [39] observed little variation in serum protein concentration in buffaloes during spring and summer seasons. Serum total protein concentrations were $44 \mathrm{~g} / \mathrm{L}$ and $51 \mathrm{~g} / \mathrm{L}$ in summer and winter seasons respectively as reported by El-Masery and Marai [40], while Yousef [41] reported slightly higher protein concentrations of 7.4 and $9.5 \mathrm{~g} / \mathrm{dl}$ in the same seasons respectively in Egyptian buffalo calves. High environmental temperature caused increase in total plasma protein in lactating cattle [42]. Serum protein concentration decreased significantly during summer season in lactating cattle [43] and buffaloes [44]. Ahmed [45] reported that the total protein levels decreased from $7.7 \mathrm{~g} / \mathrm{dl}$ in winter to $6.4 \mathrm{~g} / \mathrm{dl}$ in summer in cattle. However, Rasooli et al. [46] found a significant increase in plasma total protein from 63.88 $\pm 0.77 \mathrm{~g} / \mathrm{l}$ in winter to $69.26 \pm 0.70 \mathrm{~g} / \mathrm{l}$ in hot summer in non-pregnant Holstein heifers. In cattle, heat exposure and dehydration during heat stress resulted in sharp increase in $\mathrm{ADH}$ level which was associated with a significant decrease in urine output and a significant increase in plasma protein $[47,48]$ reported that plasma total protein content decreased by $11.9 \%$ in buffaloes and increased by $4.4 \%$ in Baladi cattle when exposed to direct solar radiations.

\section{Plasma albumin}

A significant increase in plasma albumin levels was reported in cows [40] and buffalo calves [49] during heat stress. This finding is quite relevant considering that albumin is the major extracellular source of thiols, which are scavengers of free radicals allowing albumin to function as an antioxidant [50,51], reported an increase in plasma albumin concentrations in summer $(40.23 \pm 0.38 \mathrm{~g} / \mathrm{l})$ compared to winter $(35.09 \pm 0.42 \mathrm{~g} / \mathrm{l})$ in non pregnant Holstein heifers and suggested that the increase in plasma protein concentrations might be due to the loss of extracellular fluid due to heat exposure. However, Celi et al. [52] found significantly lower plasma albumin concentration near parturition $(36.06 \mathrm{~g} / \mathrm{l})$ compared to day 21 before parturition $(39.28 \mathrm{~g} / \mathrm{L})$ in goats. This decrease in albumin levels further indicated that goats were subjected to oxidative stress during the peripartum period.

\section{Physiological responses to heat stress}

Physiological parameters like respiration rate, heart rate, body temperature and skin temperature gives an immediate response to the climatic stress and consequently the level of discomfort/comfort to the animal [53]. These responses have been used as a measure of dairy cow comfort and adaptability to an adverse environment or as a sensitive physiological measure of environmental modification [54]. Physiological responses like rectal temperature, pulse rate and respiration rate reflect the degree of stress imposed on animals by climatic parameters. The ability of an animal to withstand the rigors of climatic stress under warm conditions has been assessed physiologically by means of changes in body temperature, respiration rate and pulse rate $[55,56]$

\section{Core (Rectal) body temperature}

Change in rectal temperature has been considered an indicator of heat storage in animal's body and may be used to assess the adversity of thermal environment, which can affect growth, lactation and reproduction of dairy animals $[8,57,58]$. The rectal temperature is recognized as an important measure of physiological status as well as ideal indicator for assessment of stress in animals [59]. Even a rise of less than $1^{\circ} \mathrm{C}$ in rectal temperature was enough to reduce performance in most livestock species [60]. RT is generally considered to be a useful measure of body temperature and changes in RT indicates changes of a similar magnitude in deep body temperature $[61,62]$. The normal range in RT is very narrow in most domestic animals, not more than about $2.5^{\circ} \mathrm{C}$.

Mullick [63] reported that the rectal temperature during summer months under high and low humid conditions were always less for buffaloes than cattle. Joshi and Tripathy [64] noticed an increase in rectal temperature from $102.0^{\circ} \mathrm{F}$ to $103.8^{\circ} \mathrm{F}$ when buffalo calves were exposed to $40.5^{\circ} \mathrm{C}$ for 8 hours daily for three months. It was recorded as $2.6^{\circ} \mathrm{C}$ rise in rectal temperature in buffaloes when exposed to direct sun rays in the months of June and July. Mullick [65] reported that rectal temperature was higher during summer months in comparison to winter in Indian buffaloes. The rectal temperature was higher during summer $\left(39.83^{\circ} \mathrm{C}\right)$ than autumn $\left(38.30^{\circ} \mathrm{C}\right)$ in lactating cows $[66,67]$.

High relative humidity reduced the effectiveness of the evaporative cooling and the high relative humidity coupled with high environmental temperature apparently overwhelmed the capacity of the cow to maintain normal body temperature. It was shown that rise in air temperature (keeping humidity constant) or in humidity (keeping air temperature constant) was accompanied by rise in the rectal temperature.

The coefficient of correlation indicated that body temperature of buffaloes had highly significant correlation with seasonal changes of air temperature as determined by Chikamune and Shimizu [68]. According to Verma and Husain [69], a significant increase in the rectal temperature was observed in buffaloes during the hotter part of the year where the environmental temperature exceeded the critical limit.

The high rectal temperature observed in the heat stressed animals was the indicator of disturbance in the homoeothermic status of the animals which was not being effectively countered by the enhanced heat loss by physical and physiological processes of thermolysis [64].

\section{Respiration rate}

Respiration rate was indicator of heat stress in the hot environment and gave significant correlations with circulating corticoids 
concentration as given by Kumar [70]. Respiration rate and rectal temperature appeared to be more sensitive indicator of heat stress than pulse rate as shown by Lemerle and Goddard [71]. Normal respiration rate is approximately $10-30$ breaths/minute Hafez [72] and the respiration rate increased when environmental temperature increased [73-75] reported a very high positive correlation between the respiration rate and ambient temperature and it even raised upto 0.833 when humidity was constant in buffaloes.

An evaporative heat loss from the respiratory tract is regarded as one of the primary mechanisms for maintenance of heat balance [60]. This respiratory response arises from direct heat stimulation of peripheral receptors which transmit nervous impulses to the thermal centre in the hypothalamus. The cardio-respiratory centre is then stimulated to send impulses to the diaphragm and intercostal muscles for further respiratory activity [76]. A high RR in most cases did not necessarily indicate that the animal is successful in keeping its body temperature constant, but rather indicated that it is already overheated and trying to restore normal heat balance [60].

Respiratory rhythm proved to be a more sensitive index under tropical conditions for assessing the animal response to environmental changes and evaluating heat tolerance [77]. Respiration rate is the most consistent of all the physiological responses studied and affected more by solar radiation than by other influences [78,79] observed that increased respiration rate is the first reaction when animals were exposed to environmental temperature above the thermo neutral zone. Increase in respiratory frequency may be used an index of discomfort in large animals.

Bhatnagar and Choudhary [80] found that the combination of relative humidity and air temperature caused variation in body temperature and respiration rate of animals, whereas the relative humidity caused variation in pulse rate. McLean [81] found that the significance of increase in respiration rate under heat stress enabled the animal to dissipate the excess body heat by vaporizing more moisture in the expired air, and accounts for about 30 percent of the total heat dissipation.

Salem [82] reported an increase in respiration rate of buffaloes and crossbreds cattle during summer compared to other seasons. A higher respiration rate of $71.5 /$ minute during summer compared to 38.8 /minute in winter was recorded in lactating cows by Taneja [67], and Bianca and Findlay [84] found a highly significant increase in the ventilation rate of cattle and buffaloes with increase in the ambient temperature. Rise in air temperature appeared to be the major cause of increase in body temperature and respiration rate of dairy cows [79].

Chikamune and Shimizu [68] observed a highly significant correlation between RR and seasonal air temperature in swamp buffalo and Holstein cows when the RH was kept constant, whereas no such significant correlation was observed between RR and RH when the air temperature was kept constant. Exposure of bull calves to severe heat $\left(40^{\circ} \mathrm{C}\right)$ resulted in increase in ventilation by means of rapid and shallow breathing upto 79.0/minute [85]. Respiration rate increased from 29 to $59 /$ minute when male buffalo calves exposed to $40.5^{\circ} \mathrm{C}$ [64]. The increase in respiratory frequency was two and half times in heat stressed animals than control animals $[10,64]$ observed an increase in respiration rate from 14 to $70 /$ minute in the month of June in murrah buffalo calves when exposed to direct sunlight for 6 hours.

\section{Pulse rate}

Pulse rate did not exhibited consistant and a definite trend with changing environmental conditions. Regan and Richardson [85] observed a decrease in pulse rate whereas Gaalas [79] and Blaxter and Prince [86] observed an increase in pulse rate with increase in environmental temperature. A negative correlation was reported between air temperature and pulse rate in swamp buffaloes. Joshi et al. [87] reported that pulse rate increased moderately during exposure to hot environment in buffaloes. There was higher pulse rate during summer months and lower during winter months in Indian buffalo bulls [66]. An increase in pulse rate with an increase in air temperature in swamp buffaloes was reported. This increasing trend in pulse rate continued even when the ambient temperature declined indicating that the physiological responses of animals returned to its normal levels only after a definite period when animals were brought to comfort zone. Gangwar et al. [88] reported that environmental temperature has significant relation with the variation in the pulse rate. The result of their studies indicated that average values of pulse rate were higher during summer and lower during winter. Even it was discovered that the heart rate of calves increased during exposure to severe heat.

Radadia et al. [89] also observed a positive correlation ( $\mathrm{r}=0.234$ 0.768 ) between ambient temperature and respiration and pulse rates in buffaloes. The seemingly contradictory finding that heart rate responds to heat exposure either by a rise or by a fall may be largely explained by the fact that heart rate is positively correlated with metabolic rate [90].

\section{References}

1. Dobson H, Smith RF (2000) What is stress and how does it affect reproduction? Anim Reprod Sci 60: 743-752.

2. Rosales AG (1994) Stress syndrome in birds. Journal of Applied Poultry Research 3: 199-203.

3. Khansari DN, Murgo AJ, Faith RE (1990) Effect of stress on the immune system. Immunol Today 11: 170-175.

4. Stott GH (1981) What is animal stress and how is it measured. J Anim Sci 52 : 150-153.

5. Silanikove N, Maltz E, Halevi A, Shinder D (1997) Metabolism of Water Sodium, Potassium and Chloride by High Yielding Dairy Cows at the Onset of Lactation. J Dairy Sci 80: 949-956.

6. Salah MS, Al-Shaikh MA, Al-Saiadi MY, Mogawer HH (1995) Effect of prolactin inhibition on thermoregulation, water and food intake in heat stressed fat-tailed male lambs. Animal Science 60: 87-91.

7. Altan O, Pabuccuoglu A, Altan A, Konyalioglu S, Bayraktar H (2003) Effect of heat stress on oxidative stress, lipid peroxidation and some stress parameters in broilers. Br Poult Sci 44: 545-550.

8. West JW, Hill GM, Fernandez JM, Mandebvu P, Mullinix BG (1999) Effects O Dietary Fiber On Intake, Milk Yield, And Digestion By Lactating Dairy Cows During Cool Or Hot, Humid Weather. J Dairy Sci 82: 2455-2465.

9. Moran JB (1973) Heat tolerance of Brahman cross, buffalo, bauteng and shorthorn steers during exposure to sun and as a result of exercise. Australian Journal of Agriculture Research 24: 775-782.

10. Das SK, Upadhyaya RC, Madan ML (1999) Heat stress in murrah buffalo calves. Livest Prod Sci 61: 71-78.

11. Nardone A, Ronchi B, Lacetera N, Ranieri MS, Bernabucci U (2010) Effects of climate changes on animal production and sustainability of livestock systems. Livest Sci 130: 57-69.

12. West JW (2003) Effects of Heat-Stress on Production in Dairy Cattle. J Dairy Sci 86: 2131-2144.

13. Mader TL, Davis MS, Brown-Brandl T (2006) Environmental factors influencing heat stress in feedlot cattle. J Anim Sci 84: 712-719.

14. Trevisan M, Browne R, Ram M, Muti P, Freudenheim J, et al. (2001) Correlates of markers of oxidative status in the general population. Am J Epidemiol 154 348-356.

15. Williams CA, Kronfeld DS, Hess TM, Saker KE, Waldron JN, et al. (2002 
Citation: Ganaie AH, Shanker G, Bumla NA, Ghasura RS, Mir NA (2013) Biochemical and Physiological Changes during Thermal Stress in Bovines. J Veterinar Sci Technol 4: 126. doi:10.4172/2157-7579.1000126

Page 5 of 6

Antioxidant supplementation and subsequent oxidative stress of horses during an 80-km endurance race. J Anim Sci 82: 588-594.

16. Mann T, Keilin D (1938) Haemocuprin and hepatocuprin, copper protein compounds and liver in mammals. Proceedings of Royal Society of London Series B, Biological Science 126: 303-315.

17. McCord JM, Fridovich I (1969) Superoxide Dismutase: An enzymic function for erythrocuprein (hemocuprein). J Biol Chem 244: 6049-6055.

18. Chance B, Sies H, Boveris A (1979) Hydroperoxide metabolism in mammalian organs. Physiol Rev 59: 527-605.

19. Pathan MM, Latif A, Hemen Das, Siddique GM, Vadodaria VP (2009) Antioxidant status in periparturient Mehsana buffaloes. Revista Veterinaria 21: 748-751.

20. Bernabucci U, Ronchi B, Lacetera, N, Nardone A (2002) Markers of oxidative status in plasma and erythrocytes of transition dairy cows during hot season. J Dairy Sci 85: 2173-2179.

21. Megahed GA, Anwar MM, Wasfy SI, Hammadeh ME (2008) Influence of heat stress on the cortisol and oxidant-antioxidants balance during oestrous phase in buffalo-cows (Bubalus bubalis): thermo-protective role of antioxidant treatment. Reprod Domest Anim 43: 672-677.

22. Chandra G, Aggarwal A (2009) Effect of DL-a-Tocopherol acetate on calving induced oxidative stress in periparturient crossbred cows during summer and winter seasons. Indian Journal of Animal Nutrition 26: 204-210.

23. Lallawmkimi CM (2009) Impact of thermal stress and vitamin-E supplementation on Heat shock protein 72 and antioxidant enzymes in Murrah buffaloes. Ph.D. Thesis submitted to NDRI deemed University, Karnal (Haryana), India.

24. Oshino N, Chance B (1977) Properties of glutathione release observed reduction of organic hydroperoxide, demethylation of aminopyrine and oxidation of some substances in perfused rat liver and their implications for the physiological function of catalase. Biochem J 162: 509-525.

25. Miyazaki T, Sucoka K, Dharmarajan AH, Atlas SJ, Bulkley JB, et al. (1991) Effect of inhibition of oxygen free radical on ovulation and progesterone production by the in vitro perfused rabbit ovary. J Reprod Fertil 91: 207-212.

26. Kumar A (2005) Status of oxidative stress markers in erythrocytes of heat exposed cattle and buffaloes. MVSc. Thesis, NDRI Deemed University, Karnal, India.

27. Lallawmkimi CM (2009) Impact of thermal stress and vitamin-E supplementation on Heat shock protein 72 and antioxidant enzymes in Murrah buffaloes. Ph.D. Thesis submitted to NDRI deemed University, Karnal (Haryana), India.

28. Bisla RS, Singh J, Chawla SK, Krishnamurtthy D (2004) Assessment of ascorbic acid as an antioxidant in buffaloes during diaphragmatic herniarrhaphy. Indian Journal of Veterinary Surgery 25: 94-97.

29. Bernabucci U, Ronchi B, Lacetera, N, Nardone A (2002) Markers of oxidative status in plasma and erythrocytes of transition dairy cows during hot season. J Dairy Sci 85: 2173-2179.

30. Clemens MR, Waller HD (1987) Lipid peroxidation in erythrocytes. Chem Phys Lipids 45: 251-268.

31. Halliwell B, Chirico S (1993) Lipid peroxidation: Its mechanism, measurement and significance. Am J Clin Nutr 57: 7155-7245.

32. Chen JJ, Yu, BP (1994) Alteration in mitochondrial membrane fluidity by lipid peroxidation products. Free Radical Biology \& Medicine 17: 411-418.

33. Kumar A, Kumar P, Singh SV (2007) Oxidative stress markers profile in erythrocytes of natural and heat exposed cattle and buffalos. Indian Journa Dairy Science 60: 114-118.

34. Tanaka M, Kamiya Y, Kamiya M, Nakai Y (2007) Effect of high environmenta temperatures on ascorbic acid, sulfydryl residues and oxidized lipid concentrations in plasma of dairy cows. Anim Sci J 78: 301-306.

35. Trotta RJ, Sullivan SG, Stren A (1982) Lipid peroxidation and heamoglobin degradation in red cell exposed to t-butylhydroperoxide: effect of HMP shunt as mediated by glutathione and ascorbate. Biochem J 204: 405-415.

36. Chandra G, Aggarwal A (2009) Effect of DL- $\alpha$-Tocopherol acetate on calving induced oxidative stress in periparturient crossbred cows during summer and winter seasons. Indian Journal of Animal Nutrition 26: 204-210.

37. Aengwanich W, Kongbuntad W, Boonsorn T (2011) Effects of shade on physiological changes, oxidative stress, and total antioxidant power in Tha Brahman cattle. Int J Biometeorol 55: 741-748.

38. More T, Singh M, Rai AK (1980) Observation on excretory pattern of sodium potassium and water at different temperature. Indian Journal of Animal Science 50: $182-186$

39. Raghavan, GV, Mullick DN (1962) Effect of air temperature and humidity on the pulse rate, respiration rate and rectal temperature in buffalo bulls. Indian Veterinary Journal 38: 391-396

40. El-Masery KA, Marai IFM (1991) Comparison between Friesians and wate buffaloes in growth rate, milk production and some blood constituents, during winter and summer conditions of Egypt. Anim Prod 53: 39-43.

41. Yousef HM (1990) Studies on adaptation of Friesian cattle in Egypt. Ph.D. Thesis, Faculty of Agriculture, Zagazig University, Zagazig, Egypt.

42. Podar C, Oroian I (2003) The influence of high temperature on milk cows Buletinul-Universitatii-de-Stiinte-Agricole-si-Medicina-Veterinara-Cluj-Napoca,Seria-Zootehniesi Biotehnologii 59: 130-133

43. Marai IFM, Daader AH, Abdel-Samee AM, Ibrahim H (1997) Winter and summer effects and their amelioration on lactating Friesian and Holstein cows maintained under Egyptian conditions. International conference on animal poultry and rabbit production and health. Egyptian International Center for Agriculture, Dokki, Cairo, Egypt.

44. Verma DN, Lal SN, Singh SP, Prakash O (2000) Effect of season on biological response and productivity of buffaloes. International Journal of Animal Sciences 15: $237-244$

45. Ahmed HIA (1990) Studies on alleviation of thermal stress in imported Friesian cattle under Egyptian environmental conditions. Ph.D. Thesis, Faculty of .of Agriculture, Zagazig University Zagazig, Egypt.

46. Rasooli A, Nouri M, Khadjeh GH, Rasekh A (2004) The influences of seasonal variations on thyroid activity and some biochemical parameters of cattle. Iranian Journal Veterinary Research, University of Shiraz 5: 1383-2004.

47. El-Nouty FD, Elbanna IM, Davis TP, Johnson HD (1980) Aldosterone and ADH response to heat and dehydration in cattle. J Appl Physiol 48: 249-255.

48. Shafie MM, Badreldin AL (1962) The role of blood in regulation of body heat in bovines. Journal of Animal Production, Cairo, UAR 2: 61-76.

49. Koubkova M, Knizkova I, Kunc P, Hartlova H, Flusser J, et al. (2002) Influence of high environmental temperatures and evaporative cooling on some physiological, haematological and biochemical parameters in high yielding dairy cows. Czech J Anim Sci 47: 309-318.

50. Halliwel B (1998) Albumin-an excellent extra cellular antioxidant. Biochemica pharmacology 37: 569-571.

51. Rasooli A, Nouri M, Khadjeh GH, Rasekh A (2004) The influences of seasonal variations on thyroid activity and some biochemical parameters of cattle. Iranian Journal Veterinary Research, University of Shiraz 5: 1383-2004.

52. Celi $P$, Trana AD, Quaranta A (2008) Metabolic profile and oxidative status in goats during the peripartum period. Aust J Exp Agric 48: 1004-1008.

53. Bianca W (1965) Reviews of the progress of dairy science. Section A Physiology: Cattle in a hot environment. J Dairy Res 32: 291-345.

54. Roman-Ponce H, Thatcher WW, Buffington DE, Wilcox CJ, Van Horn HH (1977) Physiological and production responses of dairy cattle to a shade structure in a sub-tropical environment. Journal of Dairy Science 60: 424-430.

55. Leagates JE, Farthing BR, Casady RB, Barrada MS (1991) Body temperature and respiratory rate of lactating dairy cattle under field and chamber conditions. J Dairy Sci 74: 2491-2500.

56. Sethi RK, Bharadwaj A, Chopra SC (1994) Effect of heat stress on buffaloes under different shelter strategies. Indian Journal of Animal Science 64: 1282 1285

57. Johnson HD (1980) Depressed chemical thermogenesis and hormona functions in heat. In Environmental physiology aging, heat and attitude (ed. SM Horvath and MK Yousef), North Holland, NY, USA.

58. Hansen JRS, Arechiga CF (1999) Strategies for Managing Reproduction in the Heat Stressed Dairy Cow. J Dairy Sci 77: 36-50.

59. Lefcourt AM, Bitman J, Wood DL, Stroud B (1986) Radiotelemetry system for continuously monitoring temperature in cows. J Dairy Sci 69: 237-242. 
Citation: Ganaie AH, Shanker G, Bumla NA, Ghasura RS, Mir NA (2013) Biochemical and Physiological Changes during Thermal Stress in Bovines. J Veterinar Sci Technol 4: 126. doi:10.4172/2157-7579.1000126

60. McDowell RE, Hooven NE, Comoers JK (1976) Effect of climate on performance of Holstein in first lactation. Journal of Dairy Science 59: 965-973.

61. Herz A, Steinhauf D (1978) The reaction of domestic animals to heat stress. Animal Research and Development 7: 8-38.

62. Rosenberg LJ, Blad BL, Verma SB (1983) Human and animal biometeorology In: Rosenberg LJ, Blad BL, Verma SB (eds) Microclimate-the biological environment. Wiley, New York.

63. Mullick DN (1960) Effect of humidity and exposure to sun on the pulse rate, respiratory rate, rectal temperature and haemoglobin level in different sexes of cattle and buffalo. Journal of Agriculture Science 54: 391-394.

64. Joshi BC, Tripathy KC (1991) Heat stress effect on weight gain and related physiological responses of buffalo calves. Journal of Veterinary Physiology \& Allied Science 10: 43-48.

65. Mullick DN (1964) Reviews of the investigations on the physiology of Indian buffaloes. Indian Journal of Dairy Science 17: 45-48.

66. Padilla L, Matsui T, Kamiya Y, Kamiya M, Tanaka M, et al. (2006) Heat stress decreases plasma vitamin $\mathrm{C}$ concentration in lactating cows. Livestock Science 101: 300-304.

67. Taneja GC (1960) Effect of hot environment on rectal temperature, respiratory frequency and respiratory volume of calves. Indian Journal of Veterinary Science \& AH 30: 107-113.

68. Chikamune T, Shimizu H (1983) Comparison of physiological response to climate condition in swamp buffaloes and cattle. Indian Journal of Animal Science 53: 595-599.

69. Verma DN, Husain KQ (1986) Seasonal variation in rectal temperature, pulse and respiration rates of buffaloes in tropical climate. Journal of Veterinary Physiology \& Allied Science 5: 18-26.

70. Kumar V (2005) Effect of thermal stress management on nutritional, physiological and behavioural responses of buffalo heifers. P.hd. Thesis. Deemed University, Indian Veterinary Research Institute, Izatnagar.

71. Lemerle C, Goddard ME (1986) Assessment of heat stress in dairy cattle in Papua New Guinea. Trop Anim Health Prod 18: 232-242.

72. Hafez ESE (1968) Adaptation of domestic animals.

73. Bond J, McDowell RE (1972) Reproductive performance and physiological responses of beef females as affected by a prolonged high environmental temperature. J Anim Sci 35: 320-329.

74. Misra MS, SenGupta BP, Roy A (1963) Physiological reactions of buffalo cows maintained in two different housing conditions during summer months. Indian Journal of Dairy Science 17: 203-215.

75. Findlay JD, Ingram DL (1961) Brain temperature as a factor in the control of thermal polypnoea in the ox (Bos taurus) J Physiol 155: 72-85.
76. Razdan, MN, Bhoserkar MR, Roy SN (1968) Physiological behavior of Tharparkar cattle under different environments. Physiological reactors and zone of thermoneutrality. Indian Journal of Dairy Science 21: 82-86.

77. Williams JS, Shored RR, Linghton RE, Rupel IW (1960) A study of the influence of solar radiation of physiological responses of Dairy Cattle. J Dairy Res 43 1245-1254.

78. Seath DM, Miller GD (1946) The relative importance of high temperature and pulse rate of dairy cows. Journal of Dairy Science 29: 4657-472.

79. Gaalas RF (1945) Effect of atmospheric temperature on body temperature and respiration rate of Jersy cattle. J Dairy Res 28: 555-563.

80. Bhatnagar DS, Choudhary NC (1960) Influence of climate on the physiologica reactions in Murrah buffalo calves. Indian veterinary Journal 37: 404-409.

81. Mclean JA (1963) The regional distribution of cutaneous moisture vaporization in the Ayrshire calf. Journal of Agricultural Science 61: 275-280.

82. Salem IA (1980) Seasonal variations in some body reactions and blood constituents in lactating buffaloes and Friesian cows with reference to acclimatization. Journal of the Egyptian Veterinary Medical Association 40: 6372.

83. Mullick DN (1959) Energy metabolism in farm animals. II. Seasonal variation in the heat production of cattle and buffaloes. Indian Journal of Physiology \& Allied Sciences 13: 52-59.

84. Bianca W, Findlay J (1962) The effect of thermally induced hyperpnoea on the acid base balance status of the blood of calves. Research in Veterinary Science 3: 38-49.

85. Regan WM, Richardson GA (1938) Reactions of dairy cows to changes in environmental temperatures. J Dairy Sci 21: 73-79.

86. Blaxter KL, Prince H (1945) Variation in some physiological activities of dairy cows. Veterinary Journal 101: 39-45.

87. Joshi BC, Joshi HB, Guha S, Ahmad MS (1982) Physiological responses of Murrah buffalo heifers to hot arid and hot humid microenvironment. Journal of Veterinary Physiology \& Allied Science 1: 34-40.

88. Gangwar, Harish, Chandra (1988) Studies on some physiological and some biochemical parameters of blood in cross bred bulls under tropical environment M.Sc. Thesis, submitted to Deemed University, Indian Veterinary Research Institute, Izatnagar.

89. Radadia NS, Sastry NSR, Pal RN, Juneja IJ (1980) Studies on the effect of certain summer managemental practices on lactating Murrah buffaloes: 3 Physiological reactions and some attributes of blood. Haryana Agricultura University Journal of Research 10: 442-447.

90. Blaxter KL (1948) The effect of iodinated casein on the basal metabolism of the sheep. J Agric Sci 38: 207-215. 